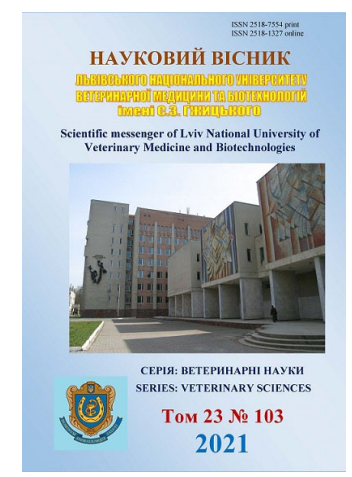

\author{
Науковий вісник Дьвівського національного університету \\ ветеринарної медицини та біотехнологій імені С.3. Гжицького. \\ Серія: Ветеринарні науки
}

Scientific Messenger of Lviv National University of Veterinary Medicine and Biotechnologies. Series: Veterinary sciences

UDC 636.5.09:577.1

\title{
Autonomous regulation of antioxidant protection and protein exchange in chickens
}

\author{
E. O. Shnurenko ${ }^{1}$, A. A. Studenok ${ }^{1}$, V. I. Karpovskyi ${ }^{1}$, V. O. Trokoz ${ }^{1}$, B. V. Gutyj ${ }^{2}$, A. Y. Torzhash ${ }^{1}$, \\ V. F. Radchikov ${ }^{3}$ \\ ${ }^{1}$ National University of Life and Environmental Sciences of Ukraine, Kyiv, Ukraine \\ ${ }^{2}$ Stepan Gzhytskyi National University of Veterinary Medicine and Biotechnologies, Lviv, Ukraine \\ ${ }^{3}$ Scientific and Practical Center of the National Academy of Sciences Belarus on animal husbandry, Zhodino, Belarus
}

Article info

Received 29.06.2021

Received in revised form 29.07.2021

Accepted 30.07.2021

National University of Life and Environmental Sciences of Ukraine, Heroiv Oborony Str., 15 Kyiv, 03041, Ukraine. Tel.: +38-050-503-57-78 E-mail: artemstudenok@gmail.com

Stepan Gzhytskyi National University of Veterinary Medicine and Biotechnologies Lviv, Pekarska Str., 50, Lviv, 79010, Ukraine. Tel.: +38-068-136-20-54 E-mail:bvh@ukr.net

Scientific and Practical Center of the National Academy of Sciences Belarus on animal husbandry, Frynze Str., 11, Zhodino, 222160, Belarus.

Tel.: +37-529-627-20-65 E-mail:arud22222@gmail.com
Shnurenko, E. O., Studenok, A. A., Karpovskyi, V. I., Trokoz, V. O., Gutvj, B. V., Torzhash, A. Y., \& Radchikov, V. F. (2021). Autonomous regulation of antioxidant protection and protein exchange in chickens. Scientific Messenger of Lviv National University of Veterinary Medicine and Biotechnologies. Series: Veterinary sciences, 23(103), 43-50. doi: 10.32718/nvlvet10307

The tone of the autonomic nervous system, protein metabolism and the activity of the antioxidant system in Cobb500 cross chickens aged 35 and 60 days were researched. The experiment involved 24 chickens, 8 in each group. In birds, the tone of the autonomic nervous system was determined by the method of variation pulsometry by recording the influence of the sympathetic and parasympathetic systems on the heart rate in chickens. The effect was determined by counting one hundred consecutive cardio intervals and the time interval between each cardiocycle. Venous blood samples were taken from each individual at the age of 35 and 60 days to determine protein metabolism (total protein, albumin, globulins), enzymatic and non-enzymatic links of the antioxidant system and lipid peroxidation depending on the tone of the autonomic nervous system. It was found that the antioxidant level in chickens with a predominance of the sympathetic division prevailed in all other groups regardless of the age of the bird. At 35 days of age, plasma concentrations of diene conjugates were significantly higher in normatonics and vagotonics $(P<0.05)$. There was a higher level of activity of ketodienes and Schiff bases in chickens with a predominance of the sympathetic division of autonomic nervous regulation compared with normotonics and vagotonics $(P<0.01)$. The content of total protein, albumin and globulins prevailed in normotonic hens and was the lowest in vagotonic hens at the age of 35 days. The two-month-old bird with a dominant parasympathetic division of the autonomic nervous system and normotonic hens had the highest levels of total protein, globulins, and conversely, sympathicotonic hens outnumbered the latter in albumin levels. Histidine content was highest in chickens with a balanced type of autonomic nervous system compared to sympathicotonics and vagotonics $(P<0.05)$. The concentration of sulfur-containing amino acid methionine was highest in vagotonic chickens $(P<0.05)$ compared with sympathicotonics. Threonine was highest in sympathicotonics compared with other groups of animals and significantly outweighed vagotonics $(P<0.05)$. The level of lipid peroxidation products in 60-day-old sympathicotonic chickens was consistently higher in contrast to normotonics and vagotonics. At the same time there was the smallest increase in the activity of diene conjugates and ketodienes $(P<$ $0.05)$ in chickens with a dominant sympathetic division of the autonomic nervous system, which indicates a slowdown in the accumulation of the final products of lipid peroxidation. It was found that the predominance of sympathetic tone is characterized by low activity of enzymes of the antioxidant system and tocopherol $(P<0.001, P<0.01)$ at 35 and 60 days of age. Indicators of the activity of the antioxidant system had the highest level in vagotonic chickens of the studied age period $(P<0.05, P<0.01, P<0.001)$. The relationship between catalase and tocopherol levels in vagotonic chickens at 35 days of age, which increases at 60 days of age $r=0.53(P<0.01)$ was found.

Key words: autonomous regulation, antioxidant system, lipid peroxidation, protein metabolism, chickens.

\section{Introduction}

The meat productivity of poultry is characterized by its ability to reach a sizeable live weight in the early stages, well-developed muscles, and a relatively poorly de- veloped skeleton to give a high slaughter yield (Patreva, 2018). The intensity of protein metabolism depends on the muscle-fat ratio, the level of protein fractions, and the content of amino acids in the serum (Gotovsky et al., 2018). It is known that the lack of at least one essential 
amino acid causes metabolic disorders, reduction or cessation of growth and development of the organism (Castro et al., 2019a; Castro et al., 2019b). Deterioration in poultry meat quality causes technological stress, which results in the excessive formation of free radicals. This process is accompanied by an intensification of lipid peroxidation, a decrease in the intensity of cellular respiration, and the activity of the antioxidant defense system (Lushchak et al., 2006). The products of free radical peroxidation can also act as biomarkers of tissue damage, as their content can be judged on the intensity of free radical processes in various body systems (Trenzado et al., 2005). Activation of lipid peroxidation is a universal damaging mechanism of cell membranes, which occurs with the formation of free hydroxyl and lipid radicals with high reactivity (Meerson, 2001).

The enzyme link and non-enzymatic compounds of the antioxidant system are involved in neutralizing free radicals, breaking down chain reactions, and removing or restoring damaged cellular components (Venditti \& Meo, 2006). Thus, $\alpha$-tocopherol has $60 \%$ antiradical action of all fat-soluble endogenous antioxidants, has the most significant ability to stabilize membranes and form complexes with fatty acids, which leads to increased resistance of membranes to free radical oxidation (Huzhahmetova \& Sentyurova, 2015).

Neuro-humoral regulation plays an essential role in the body's adaptation to changes in environmental conditions (Opalovskaya, 2001). The autonomic nervous system affects the metabolism of proteins, amino acids, glucose in the liver of animals and fish (Püschel, 2004; Vasyliv, 2017; Conde-Sieira et al., 2020; Danchuk et al., 2020a; Danchuk et al., 2020b), participates in the regulation of the activity of antioxidant defense systems and the intensity of lipid peroxidation in the body following environmental conditions (Opalovskaya, 2001).

Determining the relationship between vegetative status and protein metabolism in broilers will provide a significant impetus for further development and increased meat productivity. Studying the interaction of different levels of antioxidant protection in chickens with different autonomic nervous system tones will deepen knowledge about autonomic regulation of physiological functions. Birds to develop new methods of correcting the intensity of oxidative stress. However, studies of the vegetative regulation of protein metabolism and the intensity of antioxidant protection, its impact on productivity in birds are currently out of the attention of researchers.

The purpose and objectives of the study. To determine the effect of different tones of the autonomic nervous system on the content of protein components in the serum, products of lipid peroxidation, and the intensity of the antioxidant system in meat chickens of different ages.

\section{Material and research methods}

All animal manipulations were performed following the European Convention for the Protection of Vertebrate Animals Used for Experimental and Scientific Purposes (Official Journal of the European Union L276/33, 2010).
Studies of protein metabolism and antioxidant activity in broiler chickens, depending on the tone of the autonomic nervous system, were performed on 24 chickens of the meat direction of Cobb-500 productivity, 35-60 days of age with floor-type keeping in deep litter.

Determination of the tone of the autonomic nervous system was performed using electrocardiography. For this purpose, a portable electrocardiograph EK3T 01- "RD" with a tape speed of $50 \mathrm{~mm} / \mathrm{s}$ and an amplitude of $1 \mathrm{mV}$ was used. The electrocardiogram recording used standard leads - I left and right thoracic limbs, II - left thoracic and left pelvic limbs, III - right thoracic and left pelvic limbs. Electrocardiograms were recorded for 20-30 seconds, which allowed to record about 100-120 ECG complexes (cardio intervals). The electrocardiography procedure was performed in a quiet room without the use of sedatives. During the manipulations, the heads of the birds were covered with a cloth, which had a calming effect on the subjects. Fixation of chickens was performed in the dorsal position. Alligator-type electrodes were attached to the skin in the area of the humerus and femur. Electrocardiogram recording was started 2-3 minutes after electrode connection (Machida \& Aohagi, 2001; Reddy et al., 2016).

Spectral analysis of heart rate variability (HRV) is widely considered the standard non-invasive method of assessing autonomic nervous system function (Messina et al., 2012). Sympathetic activity is associated with low (LF; $0.04-0.15 \mathrm{~Hz}$ ), while parasympathetic activity is associated with heart rate modulation's higher frequency range (HF; $0.15-0.4 \mathrm{~Hz})$. This feature allows you to diagnose the dominant tone of the autonomic nervous system in the studied animal.

Processing the obtained electrocardiograms was performed using variation pulsometry by counting 100 R-R cardio intervals. Two main indicators were determined: mode (Mo) and mode amplitude (Amo). The duration of mode for sympathicotonic animals was $0.14-0.16 \mathrm{~s}$. (predominance of the sympathetic division of the autonomic nervous system); normotonics $-0.16-0.17 \mathrm{~s}$. (balance of tone of the sympathetic and parasympathetic divisions of the autonomic nervous system); vagotonic $-0.18-0.21 \mathrm{~s}$. (predominance of the parasympathetic tone of the autonomic nervous system). The mode amplitude is used as an additional parameter to clarify the tone of the autonomic nervous system: sympathicotonia $>45 \%$, normotony 40-45\%, vagotonia $<40 \%$ (Studenok et al., 2020). Thus, according to the results, the experimental bird was divided into three groups according to the tone of the autonomic nervous system: sympathicotonics, normotonics, and vagotonic ( 8 animals in each group).

In the second stage, venous blood was taken from each 35-day-old animal after a 2-hour fasting diet from the axillary vein. The content of lipid peroxidation products (ketodienes, Schiff bases, diene conjugates) was determined in the blood plasma by spectrophotometric method, the principle of which is based on the fact that the process of lipid peroxidation is accompanied by reorientation of double bonds with the appearance of specific optical properties (Kondrakhin et al., 2004; Danchuk et al., 2018). The level of tocopherol assessed the activity of 
the non-enzymatic part of the antioxidant system in blood plasma by liquid chromatography of vitamins extracted from biological fluids (Vlislo, 2012). Determination of the activity of the enzymatic unit of AOC was performed by studying the level of superoxide dismutase (SOD) and catalase (CAT). The CAT study technique is based on the ability of hydrogen peroxide to form a stable color complex with molybdenum salts with a maximum light absorption at a wavelength of $410 \mathrm{~nm}$ (Korolyuk et al., 1988). The level of SOD activity was determined by the method of Dubinina EE (Dubinina et al., 1983), which is based on the reduction of superoxide anions formed between phenazine metasulfate and NADPH, nitrosine tetrazolium to nitroformazone.

The content of total protein (biuret method) and albumin (bromocresol green method) in the serum was determined on a semi-automatic biochemical analyzer BiosystemsA15 (Spain) using a set of reagents PointerScientific (USA). Determination of amino acid content was performed by capillary electrophoresis on the apparatus "Drops 105M" (Komarova \& Kamentsev, 2006; Kaneko et al., 2008; Thrall et al., 2012; Corbridge, 2013).
The third stage of the study was performed at 60 days of age in chickens of different groups, in which venous blood sampling was repeated, and the products of protein metabolism, antioxidant system activity, and lipid peroxidation were determined according to the above methods.

Statistical calculations were performed using a data analysis package in Microsoft Excel 2016. In particular, the arithmetic mean (M) and its error (m) were determined, and Student's criterion determined the probability of differences in mean values. Changes in indicators were considered significant at $\mathrm{P}<0.05$ (including $\mathrm{P}<0.01$ and $\mathrm{P}<0.001)$. The correlation coefficient $(\mathrm{r})$ was calculated by the Pearson method.

\section{Results and their discussion}

Studies of the types of the autonomic nervous system in chickens showed the lowest mode rates in combination with the highest values of heart rate in sympathicotonic chickens compared with normo- and vagotonics (Table 1).

\section{Table 1}

Indicators of the tone of the autonomic nervous regulation $(\mathrm{M} \pm \mathrm{m}, \mathrm{n}=8)$

\begin{tabular}{lcl}
\hline \multicolumn{1}{c}{ ANS indicators } & \multicolumn{2}{c}{ Tone of the autonomic nervous system } \\
\cline { 2 - 3 } & Sympathicotonics & Normotonics \\
\hline Moda, sec & $0.15 \pm 0.005^{* * *}$ & Moda, sec \\
Mode amplitude, $\%$ & $53 \pm 10.4$ & Mode amplitude, $\%$ \\
Heart rate, b/min & $404 \pm 7.4 * * *$ & Heart rate, b/min \\
\hline
\end{tabular}

Note: $\mathrm{P}<0.05^{*}, \mathrm{P}<0.01^{* *}, \mathrm{P}<0.001^{* * *}$

It was found that the average value of mode in sympathicotonics was $8.5 \%$ and $12.8 \%(\mathrm{P}<0.001)$ less than normotonics and vagotonics, respectively. The increase in tonic activity in the centers of the sympathetic or parasympathetic nervous system to regulate heart rate in chickens is confirmed by the presence of correlations between the value of moda and heart rate in sympathicotonics $r=-0.6$ and vagotonics $r=-1.0$

$(\mathrm{P}<0.001)$. At the same time, normotonics have negative correlations between moda indicators and heart rate, which indicates the tendency of this type to balance the heart rhythm with the activity of the centers of the autonomic nervous system (Fig. 1).

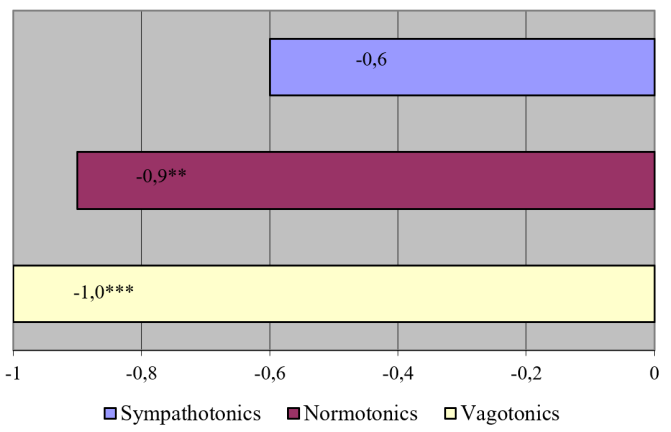

Fig. 1. Relationship between mode and heart rate depending on the types of the autonomic nervous system Note: $\mathrm{P}<0.01^{* *}, \mathrm{P}<0.001^{* * *}$
The presence of direct correlations between the mode amplitude and heart rate in chickens of all types of autonomic nervous regulation was confirmed $-\mathrm{r}=0.74-0.94$ $(\mathrm{P}<0.05-0.001)$. In vagotonic chickens, a closer interaction was found between heart rate and Amo than other ANS types (Fig. 2).

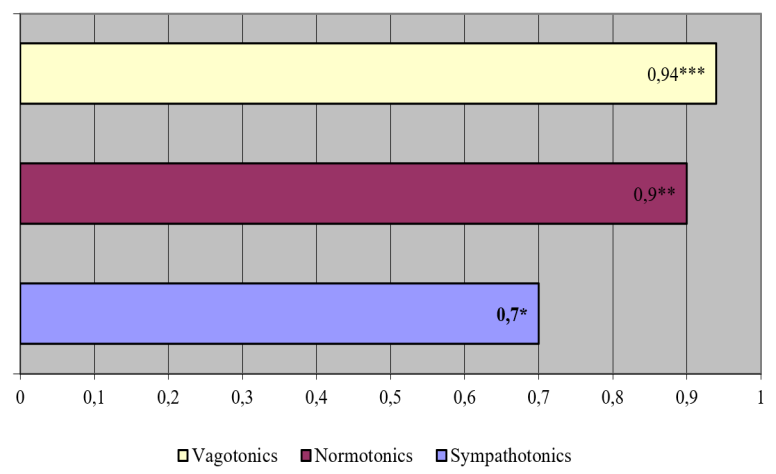

Fig. 2. Correlation of mode amplitude with heart rate in chickens with different types of the autonomous nervous system $(\mathrm{M} \pm \mathrm{m}, \mathrm{n}=8)$

Note: $\mathrm{P}<0.05^{*}, \mathrm{P}<0.01 * *, \mathrm{P}<0.001^{* * *}$

This combination and interaction of mode, mode amplitude, and heart rate made it possible to reliably determine three types of autonomic regulation in chickens, taking into account the individual characteristics of the 
tone of the autonomic nervous system, in contrast to predecessors who indicated only one type of autonomic nervous system in chickens - sympathicotonic (Tybinka, 2011).

Energy homeostasis is regulated by a complex network of neuroendocrine and autonomic pathways (Danchuk et al., 2020a). The hypothalamus plays a crucial role in monitoring the energy signal and initiating appropriate metabolic responses behavior (Esposito et al., 2016).

As a result of serum studies, it was found that 35-dayold chickens with different autonomic nerve tones have statistical differences in almost all indicators of protein metabolism (Table 2).

\section{Table 2}

Indicators of protein metabolism of chickens with a different tones of the autonomic nervous system at the age of 35 and 60 days, $\mathrm{g} / \mathrm{l}(\mathrm{n}=8)$

\begin{tabular}{|c|c|c|c|}
\hline \multirow{2}{*}{ Type ANS } & \multicolumn{3}{|c|}{ Serum content } \\
\hline & Total protein, $\mathrm{g} / \mathrm{l}$ & Albumins, $g / 1$ & Total protein, $\mathrm{g} / \mathrm{l}$ \\
\hline \multicolumn{4}{|c|}{ At the age of 35 days } \\
\hline Sympathicotonics & $39.9 \pm 1.5 * 1$ & $18.4 \pm 1.0$ & $21.6 \pm 0.6 * 1$ \\
\hline Normotonics & $43.9 \pm 1.3 * * * 1$ & $20,0 \pm 0.6 * * * 1$ & $23.9 \pm 1.0 * * 1$ \\
\hline Vagotonics & $36.3 \pm 0.8$ & $17.0 \pm 0.4$ & $19.4 \pm 0.6$ \\
\hline \multicolumn{4}{|c|}{ At the age of 60 days } \\
\hline Sympathicotonics & $39.9 \pm 0.8$ & $19.0 \pm 0.4$ & $20.9 \pm 0.5$ \\
\hline Normotonics & $41.7 \pm 1.5$ & $18.9 \pm 0.6$ & $22.9 \pm 1.0$ \\
\hline Vagotonics & $41.7 \pm 1.0$ & $18.0 \pm 0.5$ & $23.8 \pm 0.8 * * 2$ \\
\hline
\end{tabular}

Note: $\mathrm{P}<0.05^{*}, \mathrm{P}<0.01 * *, \mathrm{P}<0.001 * * *$

Total protein content in chickens with balanced ANS tone was highest at the age of 35 days and was dominated by vagotonics by $7.6 \mathrm{~g} / 1(17 \% ; \mathrm{P}<0.001)$ and sympathicotonics by $4 \mathrm{~g} / 1(9 \%)$. The difference between the latter was $3.6 \mathrm{~g} / \mathrm{l}(9 \%$; $<0.05)$. Albumin was also highest in normotonic chickens and predominated in animals with a predominance of the parasympathetic ANS branch at $3 \mathrm{~g} / 1$ $(15 \% ; \mathrm{P}<0.001)$. Sympathicotonic chickens also had a lower albumin content than normotonics by $1.6 \mathrm{~g} / 1(8 \%)$. The difference between sympathicotonics and vagotonics was $1.4 \mathrm{~g} / 1(8 \%)$. The globulin level was highest in chickens with a balanced type of ANS. Its content exceeded by $2.3 \mathrm{~g} / 1(10 \%)$ and $4.5 \mathrm{~g} / 1(19 \%$; P $<0.01)$ in chickens of sympathicotonics and vagotonics. Sympathicotonic chickens also had significantly higher globulin values than vagotonics by $2.2 \mathrm{~g} / 1(10 \% ; \mathrm{P}<0.05)$.

The increased content of albumin fraction in normotonics and sympathicotonics provides better transport of compounds - hormones, free fatty and bile acids, bilirubin (Crane \& Miller, 1977).

There is a balance of metabolic processes with age, the transition from intensive growth and building muscle mass to a plateau of stable performance. This is especially noticeable in vagotonic chickens, which increased protein metabolism and, at the age of 60, approached the results of animals with a dominant sympathetic and balanced tone of the ANS.

The dynamics of chickens' total protein, albumin, and globulin with a balanced type of ANS in 35-60 days of rearing had a dynamic to decrease. The content of fat protein decreased by $2.2 \mathrm{~g} / 1$ (3\%), albumin by $1.1 \mathrm{~g} / 1$ (6\%), globulin by $1.05 \mathrm{~g} / 1(4 \%)$. A similar trend was observed in chickens with a predominance of the sympathetic tone of the ANS. The total protein content was the same at 35 and 60 days of cultivation. Globulin and albumin fractions had slight fluctuations. Globulin decreased by $0.7 \mathrm{~g} / 1$ (3\%); albumin increased by $0.6 \mathrm{~g} / 1$ (3.2\%). Vagotonic chickens had a steady increase in serum protein fractions during the study period. Total protein and globulin fraction had a rapid increase of $5.4 \mathrm{~g} / 1(12 \% ; \mathrm{P}<0.001)$ and $4.4 \mathrm{~g} / 1(19 \%$; $\mathrm{P}<0.001)$. Albumin increased slightly by $1 \mathrm{~g} / \mathrm{l}(6 \%)$ compared to the previous period.

These changes in the protein profile of poultry may indicate an increase with age in the synthesis of protein fractions, increased immunity of birds with the vagotonic tone of the autonomic nervous system, and improved absorption of feed proteins in the body (Kuznyak \& Savchuk, 2017).

Thus, the parasympathetic division of the autonomic nervous system, influencing protein metabolism through humoral and central nervous stimulation of hepatocytes (Crane \& Miller, 1977; Püschel, 2004), causes a slow increase in serum protein levels, and the sympathetic division, on the contrary, inhibits this process.

It is known that for the synthesis of protein and peptides, the building blocks and components are amino acids, which play an integral role in the life and functioning of the whole organism (De Koning, 2013).

It was found that the content of methionine in the serum of sympathicotonic chickens 60 days of age was $2.8 \mu \mathrm{mol} / 1$ $(29 \% ; \mathrm{P}<0.05)$ lower than in birds with a predominance of the parasympathetic division of the autonomic nervous system and $0.8 \mu \mathrm{mol} / 1$ (10 \%) lower than that of normotonics. Vagotonic chickens had a $20 \%$ lower methionine content than animals with a balanced autonomic nervous system tone (Table 3). The lower range of this compound indicates its increased catabolism in animals with a predominance of the sympathetic division of the autonomic nervous system. Methionine concentration in animals may decrease due to its use as a source of metal groups in redox reactions (Garaeva, 2011; Martínez et al., 2017). This amino acid and several other sulfur-containing compounds are among the primary substances involved in neutralizing free radicals (Garaeva, 2011). 
Normotonic hens had the highest levels of histidine, which is $7.1 \mu \mathrm{mol} / 1(50 \%$; $\mathrm{P}>0.05)$ higher than that of vagotonics and $4.5 \mu \mathrm{mol} / 1(32 \% ; \mathrm{P}>0.05)$ compared with sympathicotonics.

\section{Table 3}

The content of individual amino acids in the blood of chickens with different tones of the autonomic nervous system at the age of 60 days, $\mu \mathrm{m} / 1(\mathrm{n}=4)$

\begin{tabular}{llll}
\hline \multicolumn{1}{c}{ ANS tone } & \multicolumn{3}{c}{ Amino acids } \\
\cline { 2 - 4 } & Methionine & Histidine & Methionine \\
\hline Sympathicotonics & $7.0 \pm 0.4+$ & Sympathicotonics & $7.0 \pm 0.4+$ \\
Normotonics & $7.8 \pm 0.61$ & Normotonics & $7.8 \pm 0.61$ \\
Vagotonics & $9.8 \pm 0.79$ & Vagotonics & $9.8 \pm 0.79$ \\
\hline
\end{tabular}

Note: $* \mathrm{P}<0.05$ compared with normotonics; $+\mathrm{P}<0.05$ compared with vagotonics

The difference between animals with a predominance of sympathetic and parasympathetic divisions was $2.6 \mu \mathrm{mol} / 1(27 \%)$ in favor of the latter. This distribution can be characterized by reduced metabolism and the need for amino acids as an energy source, antioxidant, and neurotransmitter in vagotonic chickens due to their predominantly less sedentary lifestyle compared to other animals (Khlybova \& Cirkin, 2006; Garaeva, 2011). The concentration of the amino acid threonine was statistically highest in sympathicotonics $(\mathrm{P}<0.05)$ and normotonics (trend) compared to vagotonics at $11 \mu \mathrm{m} / 1(43 \%)$ and $7.8 \mu \mathrm{m} / 1(34 \%)$. The difference between sympathicotonics and normotonics was insignificant and amounted to $3.2 \mu \mathrm{m} / 1$.
It is known that in the process of life, the organism in the cell is constantly formed free radicals. Dynamic growth and development, changes in physiological state, exercise, adaptation, and stress are accompanied by changes in the intensity of free radical oxidation in the body, which, on the one hand, are necessary for cell membrane renewal, synthesis of several biologically active substances, and free radical oxidation is universalmechanism of damage to biomembranes in various pathological conditions.

Studies of blood plasma in 35-day-old chickens showed a significant dependence of lipid peroxidation on the types of autonomic nervous regulation (Table 4).

\section{Table 4}

Indicators of lipid peroxidation in 35-day-old chickens depending on the types of the autonomic nervous system $(\mathrm{M} \pm \mathrm{m}, \mathrm{n}=8)$

\begin{tabular}{lcc}
\hline \multicolumn{1}{c}{ Indicators } & \multicolumn{2}{c}{ Tone of the autonomic nervous system } \\
\cline { 2 - 3 } & Vagotonics & Normotonics \\
\hline Diene conjugates, $\mathrm{D}_{278 / \mathrm{mg} \text { lipids }}$ & $0.34 \pm 0.01^{*}$ & $0.35 \pm 0.02$ \\
Ketodienes of lipids, $\mathrm{D}_{278 / \mathrm{mg} \text { lipids }}$ & $0.09 \pm 0.01^{* *}$ & $0.09 \pm 0.01$ \\
Schiff base, conventional units $/ \mathrm{cm}^{3}$ & $0.29 \pm 0.01$ & $0.02 * 30 \pm 0.02$ \\
\hline
\end{tabular}

Note: $\mathrm{P}<0.05^{*}, \mathrm{P}<0.01 * *, \mathrm{P}<0.001 * * *$

In sympathicotonic chickens, the content of diene conjugates in blood plasma was $8 \%(\mathrm{P}<0.05)$ and $11 \%$ $(\mathrm{P}<0.05)$ more than that of normotonics and vagotonics, respectively. These lipoperoxides are primary and unstable metabolites. Their large number indicates a higher level of accumulation of toxic products of lipid peroxidation in sympathicotonics compared to other groups of chickens. The activity of the formation of ketodienes and Schiff bases in chickens with a predominance of the sympathetic division of the autonomic nervous system was significantly higher than in vagotonics by $10 \%(\mathrm{P}<0.01)$ and $12 \%$ $(\mathrm{P}<0.01)$, respectively (Fig. 3 ).

The higher level of Schiff bases in sympathicotonics indicates active destabilization and damage to cell membranes, in contrast to vagotonic and normotonic chickens. This indicator is almost at the same level. This shows that the tissues of chickens with sympathicotonic tone of the autonomic nervous system are characterized by a greater intensity of lipid peroxidation. Indicators of lipid peroxidation in sympathicotonics compared with normotonics are higher, which indicates a balance in the scheme of formation and neutralization of primary products of lipid peroxidation in the latter.

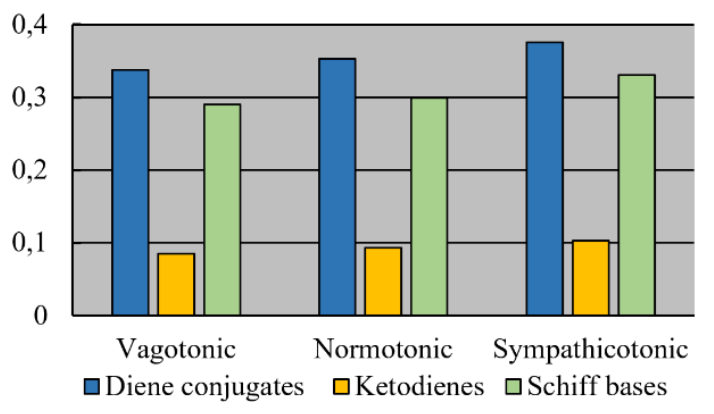

Fig. 3. Indicators of lipid peroxidation depending on the tone of the autonomic nervous system of chicken

$$
(\mathrm{M} \pm \mathrm{m}, \mathrm{n}=8)
$$

The relationship between diene conjugates $(\mathrm{P}<0.05)$ and ketodienes with the vagotonic type of regulation $(\mathrm{P}<0.01)$ tended to decrease the rate of peroxidation due to the slowing down of metabolic processes.

In 60-day-old chickens, the intensity of lipid peroxidation tended to increase. At the same time, in chickenssympathicotonics and chickens of 35 days of age, the 
highest indicators of peroxide oxidation in blood plasma are steadily defined (Table 5).

It was found that sympathicotonics at 60 days of age had the smallest increase in the activity of diene conjugates (by $3 \%, \mathrm{P}<0.05$ ) and ketodienes (by $9 \%, \mathrm{P}<$ $0.05)$ compared to 35 days. This indicates a slowing of the accumulation of toxic products of lipid peroxidation, which may be associated with more active development of enzymatic antioxidant protection with age. Normotonic hens of 60 days of age showed the highest growth rate of diene conjugates $(5 \%)$ and Schiff bases $(9 \%)$ compared to the previous study period, which may indicate an in- crease with the age of the sympathetic autonomic nervous system. Systems.

The study of the activity of the antioxidant system in 35-day-old chickens showed lower superoxide dismutase activity in birds with a predominance of the sympathetic division of autonomic regulation by $2 \%$ (trend) compared to weight tonics and $8 \%$ higher than normotonics $(\mathrm{P}<0.001)$ (Table 5). At the same time, there is a tendency to increase the activity of the studied enzymes in vagotonic chickens, which increases with age $(\mathrm{P}<0.05)$, compared with normo- and sympathicotonics.

\section{Table 5}

Indicators of lipid peroxidation in chickens 60 days of age depending on the tone of the autonomic nervous system $(\mathrm{M} \pm \mathrm{m}, \mathrm{n}=8)$

\begin{tabular}{lcc}
\hline \multicolumn{1}{c}{ Indicators } & \multicolumn{2}{c}{ Tone of the autonomic nervous system } \\
\cline { 2 - 3 } & Vagotonics & Normotonics \\
\hline Diene conjugates, $\mathrm{D}_{278 / \mathrm{mg} \text { lipids }}$ & $0.35 \pm 0.01 * * *$ & $0.37 \pm 0.013$ \\
Ketodienes of lipids, $\mathrm{D}_{278 / \mathrm{mg} \text { lipids }}$ & $0.093 \pm 0.01$ & $0.10 \pm 0.009$ \\
Schiff base, conventional units $/ \mathrm{cm}^{3}$ & $0.31 \pm 0.01 *$ & $0.33 \pm 0.01$ \\
\hline
\end{tabular}

Note: $\mathrm{P}<0.05^{*}, \mathrm{P}<0.01^{* *}, \mathrm{P}<0.001^{* * *}$

\section{Table 6}

Indicators of antioxidant system activity in chickens 35 days of age depending on the tone of the autonomic nervous system $(\mathrm{M} \pm \mathrm{m}, \mathrm{n}=8)$

\begin{tabular}{lcc}
\hline \multicolumn{1}{c}{ Indicators } & \multicolumn{2}{c}{ Types of autonomic nervous system } \\
\cline { 2 - 3 } & Vagotonics & Normotonics \\
\hline & 35 day & Sympathicotonics \\
\hline Superoxide dismutase, od. act. / mg hemoglobin & $3.2 \pm 0.09$ & $2.9 \pm 0.07$ \\
Catalase, $\mathrm{H}_{2} \mathrm{O}_{2} / \mathrm{dcm}^{3} \times \mathrm{min} \times 10^{3}$ & $70.2 \pm 3.51$ & $69.2 \pm 3.43$ \\
Tocopherol, $\mu \mathrm{mol} / 1$ & $27.9 \pm 1.16^{* *}$ & $25.72 \pm 1.1$ \\
\hline & 60 day & $24.18 \pm 0.15^{* * *}$ \\
\hline Superoxide dismutase, od. act. $/ \mathrm{mg}$ hemoglobin & $3.27 \pm 0.07^{* *}$ & $3.35 \pm 0.08$ \\
Catalase, $\mathrm{H}_{2} \mathrm{O}_{2} / \mathrm{dcm}{ }^{3} \times \mathrm{min} \times 10^{3}$ & $77.4 \pm 3.10$ & $74.6 \pm 3.32$ \\
Tocopherol, $\mu \mathrm{mol} / 1$ & $27.3 \pm 0.84^{* * *}$ & $25.3 \pm 0.73$ \\
\hline
\end{tabular}

Note: $\mathrm{P}<0.05^{*}, \mathrm{P}<0.01^{* *}, \mathrm{P}<0.001 * * *$

With age in sympathicotonic chickens, superoxide dismutase activity indicators remain lower than normotonics by $5 \%(\mathrm{P}<0.01)$ and vagotonics (trend). The level of catalase also has the lowest values compared to weight and normotonics. The lowest content of antioxidant enzymes in the predominance of sympathicotonia explains the presence of the most significant number of lipid peroxidation products, which is enhanced by intensive oxidation of free radicals in the presence of active forms of oxygen.

The phospholipid layer of the membrane is most prone to LPO, which is explained by the ability to enter into chain reactions of autooxidation of polyunsaturated fatty acids with primary free radicals. Mitochondrial phospholipids and endoplasmic reticulum membranes have a specific affinity for $\alpha$-tocopherol. The activator and medium for enzymatic reactions of cells is the phospholipid layer of the membrane. Therefore, the loss of phospholipids reduces or completely loses the activity of membrane enzymes. This explains the presence of lower tocopherol levels in sympathicotonic chickens by $6 \%(\mathrm{P}<0.01)$ compared with normotonics. In 60-day-old chickens, the intensity of tocopherol activity tends to decrease, which may indicate a decrease in the formation of free radicals and, consequently, a reduction in reactivity and consistency of the antioxidant defense system. It is proved that the level of the relationship between catalase and tocopherol increases with age in chickens of the vagotonic type of vegetative regulation $\mathrm{r}=0.53(\mathrm{P}<0.01)$, which indicates a slow but stable increase in the activity of the antioxidant system (Shnurenko et al., 2021). The vagotonics showed the highest values of tocopherol during the entire study period $(\mathrm{P}<0.01, \mathrm{P}<0.001)$, which in combination with catalase provides protection and integrity of cell membranes, interrupting the action of peroxide radicals, preventing the further formation of lipid hydroperoxide. Thus, forming complexes with fatty acids, vitamin $\mathrm{E}$ increases the resistance of membranes to free radical oxidation (Shnurenko et al., 2021).

\section{Conclusions}

The interaction of mode indicators, mode amplitude, and heart rate made it possible to reliably determine three 
types of autonomic nervous regulation in chickens (sympathicotonics, normotonics, and vagotonics). There is a significant positive linear interaction between Mo and Amo in chickens with different tones of the autonomic nervous system. In vagotonic hens, the correlation $\mathrm{r}=0.94(\mathrm{P}<0.001)$ was higher than the sympathicotonic bird $\mathrm{r}=0.7(\mathrm{P}<0.05)$, indicating a closer relationship between frequency and range of variations in vagotonics. However, the Amo rate in chickens with a predominance of parasympathetic tone was the lowest.

The influence of the tone of the autonomic nervous system on the metabolism of serum proteins in the body of broiler chickens has been established. Indicators of total protein, albumin, globulins, and urea depending on the rearing period had statistically significant fluctuations between groups of chickens. In the first period of the study (35 days of age), normotonic animals showed the highest values of blood protein fractions $(\mathrm{P}<0.01$; $\mathrm{P}<0.001)$ compared with other groups. At 60 days, sympathicotonic chickens had the highest albumin levels and the lowest content of globulin fraction compared to vagotonic animals $(\mathrm{P}<0.01 ; \mathrm{P}<0.05$, respectively). The concentration of methionine was higher in normotonics compared with sympathicotonics $(\mathrm{P}<0.05)$; histidine content was predominant in vagotonics $(\mathrm{P}<0.05)$ compared with normotonics. Threonine was higher in sympathicotonics $(\mathrm{P}<0.05)$ compared with normotonics.

The interdependence of types of autonomous regulation and lipid peroxidation is revealed. Chickens with a predominance of the sympathetic division showed a high content of lipid peroxidation products at 35 and 60 days of age $(\mathrm{P}<0.01, \mathrm{P}<0.05)$. Indicators of lipid peroxidation in normotonics are lower compared to sympathicotonics, which indicates a balance in the system of formation and neutralization of primary products of peroxidation. The lowest content of lipid peroxidation products was found in chickens with a vagotonic type of autonomous regulation $(\mathrm{P}<0.05, \mathrm{P}<0.01)$.

The relationship between the activity of the antioxidant system and the typological features of autonomous regulation has been established. The predominance of sympathicotonia is characterized by a low activity of enzymes of the antioxidant system and tocopherol $(\mathrm{P}<0.001, \mathrm{P}<0.01)$ at 35 and 60 days of age. Indicators of the action of the antioxidant system had the highest level in vagotonic chickens of the studied age period $(\mathrm{P}<0.05, \mathrm{P}<0.01, \mathrm{P}<0.001)$.

Thus, the interaction of autonomic nervous system types on protein metabolism, antioxidant system activity, and lipid peroxidation in broiler chickens was established, making it possible to predict stress resistance of these animals and adjust housing methods based on their typological features, the formation of highly productive poultry.

Prospects for further research - a study of the influence of the tone of the autonomic nervous system on the immune system and endocrine function of the endocrine glands. Relationship between the tone of the autonomic nervous system and other systems of the chicken body.

\section{Information about conflict of interest}

The authors claim that there is no conflict of interest.

\section{References}

Castro, F. L. S., Choi H. Su S., Koo, E., \& Kim, W. K. (2019a). L-Arginine supplementation enhances growth performance, lean muscle, and bone density but not fat in broiler chickens. Poultry science, 98(4), 1716-1722. doi: 10.3382/ps/pey504.

Castro, F. L. S., Kim, Y., Xu, H. et al. (2019b). The effect of total sulfur amino acid levels on growth performance, egg quality, and bone metabolism in laying hens subjected to high environmental temperature. Poultry science, 98(10), 4982-4993. doi: 10.3382/ps/pez275.

Conde-Sieira M., Capelli V., Álvarez-Otero R. et al. (2020) Hypothalamic AMPK $\alpha 2$ regulates liver energy metabolism in rainbow trout through vagal innervation. American Journal of Physiology-Regulatory, Integrative and Comparative Physiology, 18(1), 122134. doi: 10.1152/ajpregu.00264.2019.

Corbridge, D. E. C. (2013). Phosphorus: chemistry, biochemistry and technology. CRC press, 6th edition.

Danchuk, O. V., Broshkov, M. M., Karpovsky, V. I. et al. (2020b). Types of Higher Nervous Activity in Pigs: Characteristics of Behavior and Effects of Technological Stress. Neurophysiology, 52(5), 358-366. doi: 10.1007/s11062-021-09892-7.

Danchuk, O. V., Karposvkii, V. I., Tomchuk, V. A. et al. (2020a). Temperament in Cattle: A Method of Evaluation and Main Characteristics. Neurophysiology, 52(1), 73-79. doi: 10.1007/s11062-020-09853-6.

Danchuk, O. V., Karpovskyi, V. I., \& Trokoz, V. O. (2018). Antioxidant-prooxidant status in organism of pigs with different types of higher nervous activity under stress. Scientific journal "Fiziologichnyi Zhurnal," 64(4), 26-32. doi: 10.15407/fz64.04.026.

De Koning, T. J. (2013). Amino acid synthesis deficiencies. Pediatric Neurology, 113, 1775-1783. doi: 10.1016/b978-0-444-59565-2.00047-2.

Dubinina, E. E., Salnikova, L. Ya., \& Efimova, L. F. (1983). Aktivnost i izofermentnyiy spektr superoksiddismutazyi eritrotsitov i plazmyi krovi cheloveka. Lab. Delo, 10, 30-33 (in Russian).

Esposito, T., Lobaccaro, J. M., Esposito, M. G. et al. (2016). Effects of low-carbohydrate diet therapy in over weight subjects with autoimmune thyroiditis: possible synergism with ChREBP. Drug Des. Devel. Ther, 10, 2939-2946. doi: 10.2147/DDDT.S106440.

Garaeva, O. (2011). Sulfur-containing amino acids as markers of stress. Buletinul Academiei de Ştiinţe. Ştiinţele vieţii, 3(315), 50-62.

Gotovsky, D. G., Sobolev, D. T., \& Gisko, V. N. (2018). Indicators of protein metabolism of replacement chickens when they are grown in conditions with various microbial air pollution. Veterinary Journal of Belarus, 2(9), 6-8.

Huzhahmetova, L. K., \& Sentyurova, L. G. (2015). Dinamika protsessov perekisnogo okisleniya lipidov u kryis pri stresse i posle farmakologicheskoy korrektsii. Sovremennyie problemyi nauki i obrazovaniya, 4. 
URL: https://science-education.ru/ru/article/view?id= 21144 (in Russian).

Kaneko, J. J., Harvey, J. W., Bruss, M. L. et. al. (2008). Clinical biochemistry of domestic animals. Academic press, 6th edition. URL: https://www.elsevier.com/books/clinicalbiochemistry-of-domestic-animals/kaneko/978-0-12370491-7.

Khlybova, S. V., \& Cirkin, V. I. (2006). Free L-histidine as one of the regulators of physiological processes. Vyatka medical bulletin, 3-4, 44-48.

Komarova, N. V., \& Kamentsev, Ya. S. (2006). A practical guide to the use of capillary electrophoresis systems "Kapel". OOO "Veda".

Kondrakhin, I. P., Arkhipov, A. V., \& Levchenko, V. I. (2004). Methods of veterinary clinical laboratory diagnostics. Reference. M.: KolosS.

Korolyuk, M. A., Ivanova, A. I., \& Mayorova, I. T. (1988). Metod opredeleniya aktivnosti katalazyi. Laboratornoe delo, 1, 16-19 (in Russian).

Kuznyak, G., \& Savchuk, L. (2017). Protein nutrition of poultry and its dependence on age. Agricultural science and education of Podillya, 1, 334-336. URL: http://sophus.at.ua/Conf_2017/Zb_PDATU_03_2017_ p1.pdf.

Lushchak, V. I., Bagnyukova, T. V., \& Luzhna, L. I. (2006). Indices of oxidative stress. 2. Lipid peroxides. Ukr. biochemistry magazine, 78(5), 113-119. URL: https://pubmed.ncbi.nlm.nih.gov/17494327.

Machida, N., \& Aohagi, Y. (2001). Electrocardiography, heart rates, and heart weights of free living birds. J. Zoo Wild Med, 32(1), 47-54. doi: 10.1638/10427260(2001)032[0047:ehrahw]2.0.co;2.

Martínez, Y., Li, X., Liu, G. et al. (2017). The role of methionine on metabolism, oxidative stress, and diseases. Amino Acids, 49(12), 2091-2098. doi: 10.1007/s00726-017-2494-2.

Meerson, F. Z. (2001). Heart protection against ischemic lesions: the role of stress-limiting system sand stabilizing myocardial structure. Russian journal of cardiology, 5, 49-59. URL: https://russjcardiol.elpub.ru/ jour/article/view/2058?locale=en_US.

Messina, G., Vicidomini, C., Viggiano, A. et al. (2012). Enhanced parasympathetic activity of sportive women is paradoxically associated to enhanced resting energy expenditure. Auton. Neurosci. Basic Clin, 169(2), 102-106. doi: 10.1016/j.autneu.2012.05.003.

Opalovskaya, M. (2001). Circadian rhythms of autonomic parameters during mental and physical activity. Bulletin of experimental biology and medicine, 132(5), 1029-1033. doi: 10.1023/a:1017943903292.

Patreva, L. S. (2018). Tehnologiya vyrobnytstva produktsiyi ptahivnitstva: kurs lektsiy. Mykolajiv, MNAU (in Ukrainian).

Püschel, G. P. (2004). Control of hepatocyte metabolism by sympathetic and parasympathetic hepatic nerves. The Anatomical Record Part A: Discoveries in Mo- lecular, Cellular, and Evolutionary Biology, 280(1), 854-867. doi: 10.1002/ar.a.20091.

Reddy, B. S., Reddy, P. A., \& Venkatasivakumar, R. A (2016). Study on electrocardiographic patterns in turkeys (Meleagris gallopavo). Inter J. Vet. Sci., 5(2), 7982. URL: http://www.ijvets.com/pdf-files/Volume-5no-2-2016/79-82.pdf.

Shnurenko, E. O., Studenok, A. A., Gutyj, B. V., Karpovskiy, V. I., \& Trokoz, V. O. (2021). Age features of the interrelation between catalase and tocopherol activity in chickens with different types of autonomous nervous regulation. Colloquium-journal, 12(99), 1215. URL: https://journals.indexcopernicus.com/api/ file/viewByFileId/1219406.pdf.

Stalnaya, I. D. (1977). Method for determination of diene conjugation unsaturated higher fatty acids. Modern methods in biochemistry, 63-64. URL: https://chem21.info/page/02422224902622206416007 7114027067029203041198200.

Studenok, A. A., Shnurenko, E.O., Trokoz, V. O., Karpovsky, V. I., Zhurenko, O. V., \& Krivoruchko, D. I. (2020). A method of assessing the tone of the autonomic nervous system in chickens. Patent № 142943. Ukraine. u201910996.

Thrall, M. A., Weiser, G., Allison, R.W. et al. (2012). Veterinary hematology and clinical chemistry. John Wiley \& Sons, 2th edition.

Trenzado, C., Hidalgo, M. C., Garsia-Gallego, M. et al. (2005). Antioxidant enzymes and lipid peroxidation in sturgeon Acipenser naccarii and trout Oncorhynchus mykiss, A comparative study. J. Aquaculture, 254(14), 758-767. doi: 10.1007/s10695-017-0356-1.

Tybinka, A. M. (2011). Features of variation-pulsometric indexes of chickens. Scientific Messenger of LNU of Veterinary Medicine and Biotechnologies, 13(4(50)), 446-449. URL: http://nbuv.gov.ua/UJRN/nvlnu 2011_13_4\%281\%29_84.

Vasyliv, A. P. (2017). The role of types of higher nervous activity in protein metabolism in pigs. Author's ref. dis. for science. degree cand. vet. science: special. 03.00.13 - Human and animal physiology. URL: http://dglib.nubip.edu.ua:8080/jspui/bitstream/123456 789/4250/1/Vasyliv\%20A.P.pdf.

Venditti P, \& Meo, S. D. (2006). Thyroid hormoneinduced oxidative stress. Cell Mol Life Sci, 63(4), 414-434. doi: 10.1007/s00018-005-5457-9.

Vlislo, V. V. (2012). Laboratorni metody doslidzhen u biolohii, tvarynnytstvi ta veterynarniy medytsyni [Laboratory methods of research in biology, animal husbandry and veterinary medicine]. Spolom, Lviv (in Ukrainian).

Zenkov, M. K., Lankin, V. Z., \& Menshikova, E. B. (2001). Oxidative stress. Biochemical and pathophysiological aspects, Moscov, MAIK "Nauka/Interperiodika.

Crane, L. J., \& Miller D. L. (1977). Plasma protein synthesis by isolated rat hepatocytes. Journal of cell biology, 72(1), 11-25. doi: 10.1083/jcb.72.1.11. 